„Bohemistyka” 2019, nr 3, ISSN 1642-9893

Anna ZURA

DOI: 10.14746/bo.2019.3.10

Wrocław

\title{
O konceptualizacji barw raz jeszcze
}

Prezentowana monografia ${ }^{1}$, której autorem jest Richard Změlík, czeski literaturoznawca, wpisuje się w szeroki nurt badań poświęconych konceptualizacji barw. Nurt od lat konsekwentnie rozwijany przez badaczy różnych specjalności. Ogrom publikacji z tego zakresu odnosi się do języka w kontekście zarówno filologicznym, jak i kulturowym, a wnioski badawcze są stawiane na bazie integracji z wynikami z obszaru eksperymentów psychologicznych, fizycznych, a nawet odkryć neurologicznych. Pozwala to na pełniejszy, bardziej syntetyczny opis samego języka, jak też opis dzieła literackiego, będącego wyrazem szczególnej kreacji autorskiej.

Odwoływanie się do innych obszarów wiedzy, aniżeli tych stricte filologicznych, znalazło swoje miejsce zwłaszcza w lingwistyce, z powodzeniem rozwijającej koncepcję metody badań językowego obrazu świata (JOS). W efekcie tego mamy dostęp do poznania zjawisk językowych determinowanych przez różne kultury, które są nośnikiem własnych, często narodowych, doświadczeń w ujęciu synchronicznym i diachronicznym. Na tym tle możemy też odkryć indywidualną kreatywność poszczególnych jednostek, twórców literatury, których dzieła mogą być determinowane przez własne indywidulane, często niepowtarzalne, doświadczenia. W efekcie dzieła te pozwalają na odczytanie zjawiska pewnego balansowania pomiędzy szeroko pojętym uniwersalizmem językowym a relatywizmem kulturowym.

Omawiana monografia Richarda Změlíka stanowi analizę konceptualizacji barw w literackiej twórczości prozatorskiej wybitnego czeskiego autora Jana Čepa i wpisuje się w krạg badań literaturoznawczych, pomimo że Změlík stosuje także narzędzia przypisane analizom lingwistycznym. Już na wstępie autor monografii zaznacza, że jego praca „se na první pohled možná nemusí jevit jako standardní literárněvědná studie, ale spíše jako práce lingvistická, přesto právě do oblasti literární vědy náleží především" (s. 9).

Należy też zaznaczyć, że Změlík ma już za sobą podobny eksperyment (zakończony sukcesem), kiedy pochylił się nad analizą twórczości Čepa, wykorzystując narzędzia stricte z obszaru badań językoznawczych, a efektem tego eksperymentu było opublikowanie książki Kvantitativně-korpusová analýza a literární véda... (2015) oraz szeregu artykułów w czeskich i zagranicznych czasopismach recenzowanych.

1 Richard Změlík, Konceptualizace barev v narativni fikci na pozadi kvantitativnich modelů, Olomouc: Univerzita Palackého v Olomouci, 2019, 320 s. 
Natomiast w monografii Konceptualizace barev... (2019) jej Autor stawia sobie trzy główne cele: zintegrowanie metod badań lingwistycznych i literaturoznawczych; przetestowanie wybranych metod (określenie ich potencjału, ale także ograniczen w kontekście nauk o literaturze) oraz dokonanie próby połączenia obu możliwości metodologicznych poprzez poszerzenie interpretacji literaturoznawczych. Tak więc jest to praca nie tylko z zakresu semantyki, konceptualizacji barw w literackiej prozie Jana Čepa, ale przede wszystkim jest ona opisem eksperymentu metodologicznego. Biorąc pod uwagę fakt, że Změlík ma już w swoim dorobku publikację, w której odważył się na próbę integracji metod (2015), to Konceptualizace barev... (2019) faktycznie jest pogłębionym spojrzeniem doświadczonego i dojrzałego badacza, który śmiało przekracza kolejne granice w eksploracji bogatego materiału.

Autor zaznacza, że praca została podzielona na cztery zasadnicze części i zaczyna się od przedstawienia stanu badań. Nastepnie, na potrzeby tejże pracy, opisano formułę przejścia od narzędzi lingwistycznych do literaturoznawczych, a w kolejnej części przeprowadzono dogłębną analizę materiału, stosując narzędzia modeli ilościowych, by finalnie podzielić się wynikami z zakresu fikcjonalnej semantyki barw w prozie Jana Čepa oraz na tej bazie dokonać interpretacji literaturoznawczej.

W części pierwszej monografii Richard Změlík dokonuje opisu stanu badań nad barwami w przestrzeni filologicznej z perspektywy synchronicznej i diachronicznej ze szczególnym uwzględnieniem dorobku językoznawców. Odwołuje się zatem do klasycznej publikacji Berlina i Kaya (1969), opis wzbogaca szeregiem diagramów i wykresów ukazujących spektrum barw i przyporządkowane do nich nazwy, wskazujacc na problem rozmycia granic znaczeniowych, które wywołuja wạtpliwośc w jednoznacznym przyporządkowaniu nazwy do desygnatu. Autor opisuje zjawisko konceptualizacji, traktując je jako proces zmysłowo-mentalnie-językowy.

Następnie na bazie osiagnięć lingwistycznych wskazuje na osobliwość tzw. semantyki fikcjonalnej, która jest efektem różnorodnych warstw strukturalnych w dziele literackim i procesów z nim związanych. Zdaniem autora, owe warstwy i procesy pozostaja w centrum metod literaturoznawczych i sa tak samo istotne jak konteks i recepcja dzieła. Změlík przedstawia przy tym interesujący schemat przeciwstawnych trójkątów, obrazujący różne obszary dzieła literackiego, a które stanowią punk wyjścia do szeroko pojętych, integracyjnych badań lingwistycznych i literaturoznawczych.

W tej części pracy nie brakuje także opisu algorytmów barw w ujęciu lingwistycznym, dla którego punktem wyjścia była publikacja Adama Pawłowskiego (2006), pozwalajaca na stworzenie pewnego fundamentu do zastosowania metody badań, których osią są ilościowe modele językowe.

Koncepcja JOS, będaca fundamentalna metoda analizy barw w recenzowanej pracy, jest też opisana w odniesieniu do badań czeskich lingwistów - także w perspektywie synchronicznej i diachronicznej. Autor kontynuuje swoje rozważania na temat roli barw w innych dziedzinach, które wpisują się w obszar ogólnie pojętej kultury czeskiej: w literaturze, sztuce, folklorze.

W części tej Změlík formułuje istotny wniosek, który jednocześnie stanowi wstęp do zasadniczej części pracy:

Z literárněvědného hlediska se však otázka jazykového obrazu světa utvářeného skrze jazyk literárního díla jeví poněkud komplikovaněji. Především literární dílo jednoduše neodkazuje k přirozenému světu, ke světu reálnému či aktuálnímu, ale generuje fikční svět. Funkce literárního jazyka nespočívá primárně v referenčním aktu, [...] ale v aktu performativním (s. 86).

W drugiej części recenzowanej monografii autor skupia się na tzw. fikcjonalnej semantyce barw (fikčni sémantika barev), którą traktuje jako swego rodzaju przejście od rozważań nad znaczeniem barw w kontekście lingwistycznym do osadzenia ich w przestrzeni nauk o literaturze. Szczegółowo wyjaśnia pojęcie konceptualizacji, przede wszystkim opierając się na jej rozumieniu na sposób Lakoffa i Johnsona (1980). Sam jednocześnie opisuje zjawisko konceptualizacji drugiego stopnia, które łączy w odniesieniu do światów fikcyjnych, wymyślonych. Tym sposobem, mówiąc o tym typie konceptualizacji, operuje pojęciem fikcjonalizacja (fikcionalizace).

W kolejnym etapie rozważań czytelnik może się zapoznać z aspektami teoretycznej analizy dyskursu. Istotna częścią tych dociekań jest kwestia modelowania i swoista dokładność, zwłaszcza że modelowanie jest ważną częścią badań literaturoznawczych autora monografii.

Trzecia cześć pracy Richarda Změlíka jest już wprawna analizą barw poprzez zastosowanie tzw. modeli ilościowych. Dzięki temu czytelnik recenzowanej pracy ma dostęp do szczegółowego opisu metody, która bezsprzecznie stanowi precyzyjną instrukcje, w jaki sposób praktycznie pracować z materiałem korpusowym. Opis ten ma też wymiar pragmatyczny, pozwalajacy na zdobycie umiejętności zastosowania wspomnianej metody, również do analizy innych tekstów literackich, co pozwoli na uzyskanie dodatkowych, poszerzonych wyników interpretacji dzieła literackiego.

W trzeciej części została przeprowadzona analiza o charakterze porównawczym. Jej podstawą jest bogaty materiał wyekscerpowany z wybranych korpusów językowych i tzw. subkorpusów. Změlík wprawnie analizuje profile frekwencyjne barw w czeskim korpusie językowym (SYN 2015), zestawiając go z korpusem brytyjskim (British National Corpus - BNC).

Autor w tym kontekście opisuje zjawisko konotacji barw: wskazuje na ich znaczenie podstawowe, z którego wypływają znaczenia systemowe. Na tej bazie uzasadnia istnienie konotacji tekstowych, które są w zakresie koncepcji semantyki fikcjonalnej.

Zadanie zbadania znaczeń barw zostało zrealizowane w oparciu o materiał korpusów: SYN 2015, SYN FIC (korpus beletrystyki), SYN FIC NOV (korpus prozy), SYN FIC VER (korpus poezji), oraz korpusów autorskich: HRABAL (korpus prozy B. Hrabala), ČAPEK (korpus prozy K. Čapka), MÁCHA (korpus prozy K.H. Máchy) 
oraz ČEP (korpus prozy J. Čepa). Jako że przedmiotem badań Richarda Změlíka jest przede wszystkim proza Jana Čepa, poddaje ją więc szczegółowej analizie, czerpiąc materiał z poszczególnych utworów: Vigilie (1928), Zeměžluč (1921), Letnice (1932), Tvár̆ pod pavučinou (1941), Cikáni (1999), Hranice stínu (1935), Děravý plášt' (1934), Polní tráva (1946), Dvoji domov (1926), Modrá a zlatá (1938).

Dokonując analizy korpusowej nazw barw, Změlík prezentuje cały przekrój zróżnicowanych wykresów, zestawień wskazujących opozycje semantyczne barw w poszczególnych utworach oraz zestawień klasyfikacyjnych i hierarchicznych.

Należy jednak z całą moca podkreślić, że autor nie koncentruje się li tylko na samych obliczeniach i wykresach, słusznie wskazuje, że ,....nelze spoléhat na kvantifikaci izolovaných kategorií barev, ale je nezbytné je nahlížet v různých kontextech. [...] ve výsledku nás nebude zajímat lexikální kontext dané barvy, ale kontext celého fikčního světa, způsob konceptualizace barvy ve fikčním světě” (s. 151). Dodaje także:

Je však nezbytné nezůstávat pouze u popisu jednotlivých modelů a chápat je ve funkčních korelacích. Jak se rovněž ukáže v pátém oddíle, jejich aplikace na konkrétní materiál nespočívá v jejich prostém přiřazení ke konkrétnímu textu. Není možné a priori vycházet výhradně z těchto modelů a jim za každou cenu přizpůsobit výklad, ale udržovat mezi literárněvědnou interpretací a kvantitativními modely funkčně korelační vztah. Pouze takto lze rozumět pojmu řízená literárněvědná interpretace (s. 191)

Ostatnia, finalna część pracy - Fikční sémantika barev v próze Jana Čepa - literárněvědná interpretace na bázi kvantitativních modelů - wydaje się być najbardziej interesująca, a z pewnością odkrywcza. Autor skupia się w niej bowiem bezpośrednio na analizie i interpretacji prozatorskich tekstów Jana Čepa z zastosowaniem fikcjonalnej semantyki barw. Wśród wielu interesujących odkryć i idących za nimi wnioskami, wynikającymi z analizy semantyki barw oraz ich interpretacji, autor monografii wskazuje m.in. na silną oś kontrastu barw na linii chromatyczności i achromatyczności, identyfikuje w prozie Čepa zjawisko rytmiki oraz swoisty kontrapunkt, wyprofilowany poprzez nazwy barw. Warta uwagi jest także część wskazująca na intensywność nasycenia światłem wykreowanego, autorskiego świata fikcji. Změlík konstatuje także, że ,ve fikčních světech však barvy nevyjadřují pouze příznak ročního období, ale do jejich významového plánu se promítají sémantické rezultáty metafyzických a symbolických konstrukcí. [...] Barevná tonalita fikčních prostoru má tedy ve výsledku povahu palimpsestu; vztahuje se $\mathrm{k}$ jevovému světu a jeho prirozeným barvám, avšak současně jej dalece překračuje směrem do oblasti světa duchovního, světa vyměřeného jedině skutečným a intenzivním prožitkem křest'anské víry" (s. 266).

To najbardziej zajmująca cześć w całej pracy Richarda Změlíka, w której czytelnik może zapoznać się z wynikami przeprowadzonej analizy i interpretacji. I szczególnie do tej części, nie zdradzając jej zawartości, należy zachęcić odbiorcę. Wyniki rzetelnej analizy opartej na zastosowaniu narzędzi zarówno z obszaru badań językoznawczych, jak i literaturoznawczych stanowią nowe spojrzenie na prozę Jana Čepa.

Cała monografia jest poparta rzetelnym materiałem badawczym, ujętym w postaci aneksu (s. 277-297), na który składają się zestawienia frekwencji nazw barw, zestawienia konkordancji nazw barw w wybranych korpusach językowych oraz inne. Praca zawiera streszczenie w języku angielskim (s. 299-301), bibliografię (s. 303-314) oraz indeks autorów (s. 315-317).

Konkludując, należy uznać, że monografia Richarda Změlíka Konceptualizace barev... (2019) ma charakter nowatorski, pomimo że - jak wspomniano wcześniej przestrzeń semantyki barw została już wyjątkowo wyczerpująco opisana. Jednakże w przypadku recenzowanej pracy mamy do czynienia z wprawnym łączeniem metod z obszaru badań lingwistycznych i literaturoznawczych. Stąd też należy powtórzyć za autorem, że rzeczywiście jest to rozprawa o metodzie, która w wydatny sposób poszerza obszar poszukiwań i odczytań tekstów literackich. Monografia ta rzuca także nowe światło na interpretację twórczości literackiej Jana Čepa ze szczególnym uwzględnieniem konceptualizacji barw w prozie kwalifikowanej do tzw. fikcji narracyjnej.

Praca z pewnością okaże się być cenna pozycją dla badaczy, którzy są otwarci na działania eksperymentalne, co pozwoli im wzbogacić przekrój innowacyjnych wniosków, wynikających z tak poprowadzonej analizy. Zatem monografia Richarda Změlíka może stanowić punkt wyjścia do dalszych badań na polu interpretacji dzieła literackiego, ale także może być nowoczesnym zapleczem uzupełniającym interpretację prozy Jana Čepa na poziomie opracowań akademickich.

\section{Literatura}

B e r l in B., K a y P., 1969, Basic ColorTerms. Their Universality and Evolution, Berkeley - Los Angeles, University of Califinia Press.

Č e p J., 1926, Dvoji domov, Praha: Ladislav Kuncíi

Č e p J., 1928, Vigilie, Praha: Rudolf Škeřik.

Č e p J., 1931, Zemeżluč, Praha: Melantrich.

Če J., 1932, Letnice, Praha: Melantrich.

Č e j., 1934, Déravy plašt, Praha: Melantrich.

Č e j., 1935, Hranice stinu, Praha: Melantrich.

Č e p J., 1938, Modrá a zlatá, Praha: Melantrich.

Č e p J., 1941, Tvár pod pavučinou, Praha: Vyšehrad.

Č e p J., 1946, Polni tráva, Praha: František Borový.

Č e p J., 1999, Cikáni a jiné prózy, In: Čep J., Polni tráva, Praha: Vyšehrad, s. 305-375.

L a k off G., J o h n s on M., 1980, Methaphors we live by, Chicago: University of Chicago Press.

P a w o w s k i A., 2006, Quantitative Linguistics in the Study of ColourTerminology. A Research Report. In Biggam C.P., Kay C.J. (eds.), Progress in Colour Studies. Volume I. Language and Culture, Glasgow: University of Glasgow, s. 37-55.

Z m ělík R., 2015, Kvantitativně-korpusová analýza a literárni véda: model a realizace autorského korpusu a slovniku Jana Čepa v kontextu zahranični a české autorské lexikografie, Olomouc: Univerzita Palackého v Olomouci. 